\title{
Educational Innovation and the Market for Geographers in Hungary
}

\author{
GÁBOR MEZÕSI, LÁSZLÓ MUCSI \& ÁBEL GARAMHEGYI, University of \\ Szeged, Hungary
}

ABSTRACT This paper examines the status of geography in higher education in Hungary. Stress is placed on reforms begun in the 1990s to launch new curricula for training professional geographers. The authors played an important role in developing this new curriculum by introducing new subjects into geography programmes, working out the scope and sequence of courses, obtaining accreditation and carrying out market research for graduates. The project was motivated by a decline in demand for geography and geography teachers in secondary schools accompanied by an increase in demand for geographers trained to work in public administration, government and business. The graduates of the new professional geographer curriculum receive a practice-oriented education designed to cultivate their spatial problem solving and applied geographical skills. In this paper the authors present the steps in the curriculum reform and suggest that it may serve as a model for reform in a number of nearby countries planning to join the $E U$.

KEYWORDS Hungary, curriculum reform, employment trends, market research.

\section{Introduction}

In Hungarian universities, geography is a very old subject but, in many respects, a very new discipline. Budapest's Technical University established a department of geography and statistics in 1863, with geography appearing as a separate department in 1870 (the fifth in Europe) with János Hunfalvy as its first professor. For well over one hundred years, Hungarian universities have provided strong programmes in geography, focusing especially on teacher training. Yet the discipline has also responded to major curriculum reform efforts begun in the 1980 s and 1990s because, like their neighbours in central and eastern Europe, Hungarian universities faced the issue of modernising their curricula and preparing their graduates to meet changing workforce needs. The work of the social geography research group under Enyedi $(1984,1988)$ and the environmental geography research group under Pécsi (Pécsi \& Rétvári, 1984), provided the rationale for at least 


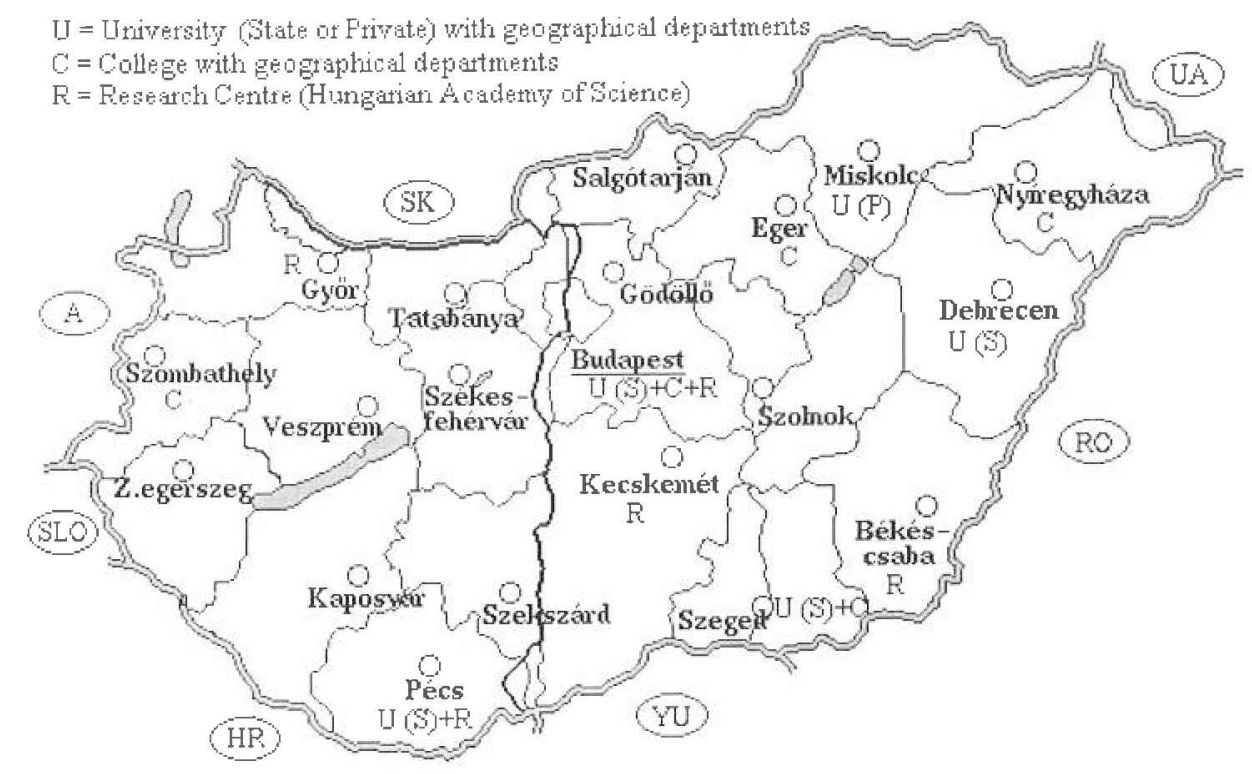

FigurE 1. Location of Hungarian Universities and Colleges with geography departments and Geographical Research Centres of the Hungarian Academy of Sciences.

two major new specialisations for professional geographers: urban planning, including regional development and environınent; and landscape planning.

Beginning in 1993, a new curriculum was implemented for training these professional geographers equipped to work in government and business. The authors, based at Szeged University, were instrumental in Iaunching this course, shaping its core curriculum and organising its accreditation. As part of the first five-year audit of this course performed in 1998, extensive marketing research was undertaken to estimate the demand for these new professional geographers as well awareness of the programmes among employers. These are important considerations because in Hungary, as in other nations, employers are not always aware of the potential benefits of hiring university graduates trained to address geographical, spatial and environmental issues.

\section{Geography in Hungarian Higher Education}

In Hungary at the present time, there are 19 geography departments in the country's five major universities and separate departments in four colleges. These departments are distributed quite evenly across the county with the university programmes located in the nation's largest cities: Budapest, Szeged, Debrecen, Pécs and Miskolc (Fig. 1). Those universities with more than one department offer separate and administratively distinct courses in physical and human geography, sometimes also in regional geography, landscape ecology (as in Debrecen) and applied geoinformatics (as in Szeged). This separation can be traced back to the traditional research fields of the different universities: in Budapest geomorphological research is the most important, in Debrecen landscape ecology and in Szeged applied geomorphology.

Approximately 1600 students are enrolled in the university courses with another 1200 
in the college programmes. All together, geography accounts for about 1.2 per cent of the total student enrolment in higher education. The students are taught by 200-250 university and college teachers. In the country as a whole, there are approximately 200-250 persons employed as professional geographers and 1200-1400 geography teachers in the primary and secondary schools. Beginning in 1999, with the support of the World Bank, Hungary has started consolidating a number of heretofore separate colleges and universities in Szeged and Debrecen into single, integrated institutions. The result will be a union of departments in these institutions and the end of parallel programmes in different fields of geography.

In Hungary, pre-collegiate education is divided into eight years of primary school and four of secondary, with attendance required for the first 10 years. Upon completion of secondary school, students can study geography at three different levels. A student who finishes eight semesters (four years) receives the 'college diploma' and is qualified to teach geography in primary schools to 10 - to 14-year-olds. Students who continue for 10 semesters (five years) receive a diploma in geography teaching (the qualification for teaching at the secondary level) or a diploma in professional geography. The college diploma is equivalent to the Anglo-American BA degree; the university diplomas are comparable to the MA. Postgraduate programmes lead to the $\mathrm{PhD}$ degree, but the Hungarian Academy of Sciences awards the highest scientific degree, the DSc, under further procedures.

In accordance with Hungarian higher education law, university students must pass a final examination at the end of their tenth semester. Furthermore, students, whether in the teaching or professional courses, must submit a thesis to a board of examiners in their final year. The credit system for classes and seminars, due to come into effect in 2002, is based on 'work units', roughly hours per week on a given subject. A minimum of 300 work units is required for graduation.

In addition to the undergraduate programmes, most of the universities have elected to launch postgraduate programmes of six semesters leading to the $\mathrm{PhD}$ degree. Almost 100 $\mathrm{PhD}$ students participate in the different postgraduate programmes. Doctoral students often spend part of their programmes at other European universities. Several exchange programmes, such as ERASMUS, support these visits.

Traditionally, geography has played an important role in primary and secondary schools, though this situation has been changing in the past few decades. In the 1970s and again in the 1990s, Hungarian students achieved high scores in international surveys. The most recent average score, 71.2 per cent, placed Hungarian students in third place internationally, far beyond the mean of 55.7 and above students in Germany 61.2, Austria 66.5, Belgium 43.7, UK 50.8, USA (San Diego) 54.7 and Italy 56.6 per cent (Haubrich, 1996). The sample included 1000-1500 students per country. At the same time, however, there has been a decrease in the time allotted to geography in Hungarian schools. In 1949, students studied geography 4 hours per week in grades 5-7, 3 hours per week in grades $8-10$, and 2 hours per week in grade 11 , for a total of 23 hours of 'tuition time' (hour/years) of geography over the period of their primary and secondary schooling. In 1965, this was reduced to 2 hours per week across grades 5-11, for a total of only 14. In 1990, geography was removed from grades 5 and 11 and, although an extra hour was added for grade 9, the total fell to 11, already less than the 12 hours specified in nations such as Slovenia and Poland (Probáld, 1998). In 2002, total tuition time spent on geography in Hungarian primary and secondary schools will be reduced still further to 8 . Less attention in the schools has not, necessarily, reduced the demand for geographers. Indeed, the curricular innovations reported here are a response 


\section{G. Mezõsi et al.}

to the changing educational, economic and political conditions in Hungary. They involve a renewal of content and form as well as greater awareness of the need to prepare students for professional careers and to market their skills among employers.

\section{Changes in Geography since 1990: new and modernised curricula}

After the change of regimes, local authorities assumed greater importance in supplying foreign investors with the data they needed for planning and decision making, particularly spatial information. Experts carried out the analysis and interpretation of the spatial information, but these individuals often lacked the qualifications attained by professional geographers and geography teachers educated in universities of science and technology. As this demand for professionally trained geographers increased, other conditions raised questions about the future demand for geography teachers, the traditional focus of college and university instruction. By 1991-92 it became clear that higher education could expect as much as a tripling of student numbers (from the earlier 12-14 per cent of the age cohort to 30-35 per cent). It seemed unreasonable to expect the demand for geography teachers to increase at this same rate given that fewer hours of instruction in geography will be delivered in schools after 2002 and that the age cohort of 12- to 16 -year-olds has been falling. In the context of these developments, it seemed important to renew and modernise the geography curriculum in higher education.

\section{Organisation of the Curriculum for Professional Geographers}

We had definite ideas about what needed to be done. Although the term "professional geographer' has long carried a pejorative connotation in Hungarian signifying an individual lacking academic credentials, though perhaps skilled in exploration, travel and discovery, we felt this image could be changed. We envisioned training a new type of geographer, a practice-oriented individual skilled at solving applied geographical and spatial problems.

In 1991-1992, we were given the opportunity to begin developing our plan. The Hungarian government planned to increase the number of students at the universities, but not to increase the size of geography teacher training programmes. This policy decision, along with a real increase in market demand for geographers, suggested only one solution: a programme of education for professional geographers. By early 1992, after numerous discussions and meetings, our plan for a new curriculum for professional geographers was approved. It was put into practice first in Szeged and Budapest in 1993, in Debrecen in 1994, Pécs in 1997 and finally Miskolc in 1998. At present, approximately 800 students are enrolled nationally in the professional geographers' courses, while another 800 are training as geography teachers. The trend, at least at Szeged, is increasing demand for the professional geographers' course and decreasing demand for teacher preparation (Fig. 2).

\section{The Structure of the Curriculum of Professional Geographers and Its Reform.}

Professional geographers and geography teachers follow parallel, though not identical programmes for their first four semesters (http://www.sci.u-szeged.hu/oktatas/foldrajz/index.html). It is in the fourth semester that the two programmes begin to diverge considerably with the professional geographers selecting an accredited subject in which 


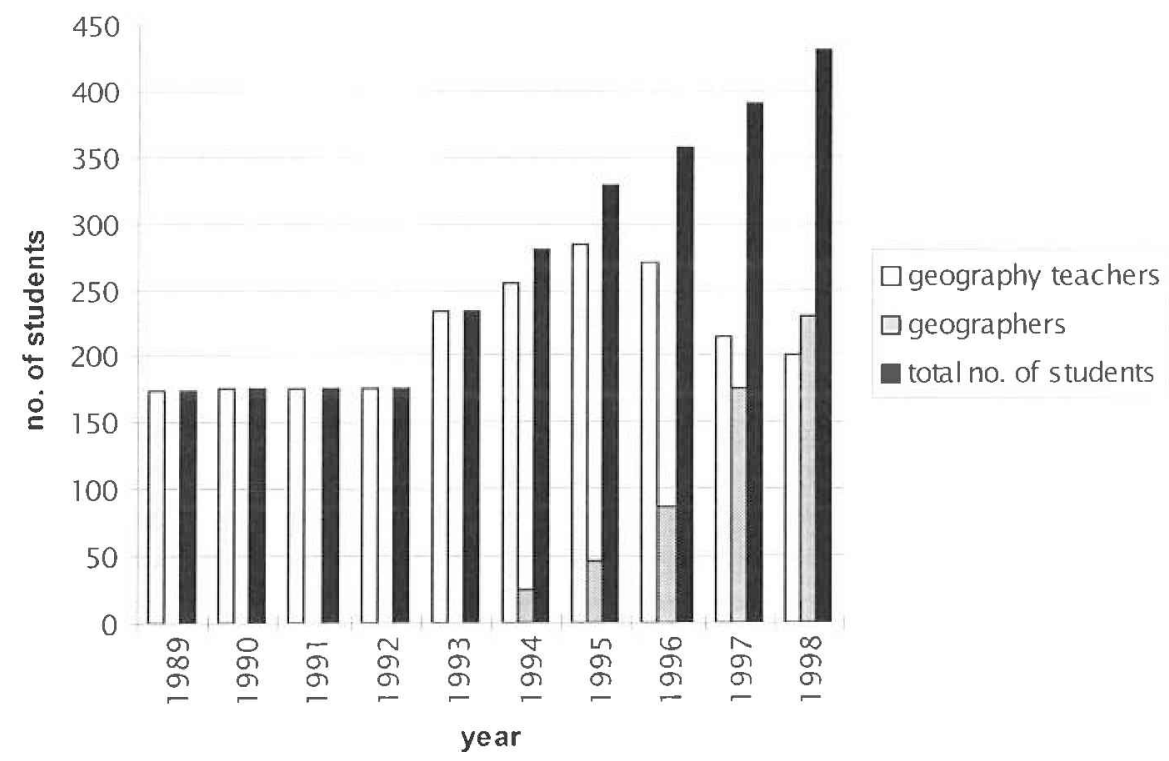

FIGURE 2. The number of students studying to be professional geographers or geography teachers in the Faculty of Sciences at the University of Szeged, 1989-1998.

to specialise (Table I). From the fifth to tenth semesters, students follow a core curriculum in their specialisation including both theoretical and practical topics.

The first problem we addressed in developing the curriculum was to strengthen the role of the basic sciences in the first four semesters of the course. This was aimed at remedying any deficiencies in the students' secondary education as well providing them with a strong theoretical foundation for their later coursework. In the first two semesters the subjects studied by the teachers and professional geographers are the same, but later the teachers study pedagogy whereas the professional geography students enrol in mathematics, chemistry and biology. This background prepares them for the geochemistry, quantitative physical geography and biogeography topics that come later.

The second problem we addressed was to improve the students' individual research

TABle I. Geography courses in Hungarian universities and specialisations offered.

\begin{tabular}{|c|c|}
\hline University & Specialisation \\
\hline Eötvös Lóránd University-Budapest & $\begin{array}{l}\text { Regional and Urban Planning } \\
\text { Environmental Planning }\end{array}$ \\
\hline Szeged University-Szeged & $\begin{array}{l}\text { Regional and Urban Planning } \\
\text { Envirommental Planning } \\
\text { Geoinformatics } \\
\text { Geology }\end{array}$ \\
\hline Kossuth Lajos University-Debrecen & $\begin{array}{l}\text { Regional and Urban Planning } \\
\text { Environmental Planning }\end{array}$ \\
\hline Janus Pannonius University-Pécs & No Specialisation \\
\hline Miskolc University-Miskolc & No Specialisation \\
\hline
\end{tabular}




\section{G. Mezõsi et al.}

and problem-solving skills. In evaluating student feedback, it became evident that students needed to start their individual research relatively early in the course to gain the experience they would need in professional practice. Though they write their theses in the seventh and eighth semesters, the students are asked to choose their topic in the fifth and sixth semesters. During these terms, the students write an essay on their topic that is presented for discussion to a board that comprises lecturers, researchers and students from the geosciences departments.

The third and a most complex problem to sort out was the modernisation or elimination of some specialised classes, the introduction of new classes, and increasing the proportion of specialised to basic training in the programme. Indeed, rapid changes in some areas-such as technology - have even required that we update the curriculum we first proposed in 1992. We could not ignore the technological innovations occurring in geoinformatics, remote sensing, computer research techniques, and access to the Internet and Worldwide Web (making possible, for instance, the use of global databases). New methods and devices of measurement and observation (e.g. GPS, continuous, real-time digital monitoring) also had to be introduced. In the end, we developed new classes in GIS, remote sensing, digital cartography, landscape ecology and regional processes of Europe for the programme.

Other previously existing specialised courses were renewed and new classes introduced in regional planning, urban ecology, logistics, the economics of tourism, environmental geology, geomathematics and statistics, landscape ecology planning, and project management. Two of the most important specialised topics we launched were geoinformatics and geology. The former was set up to satisfy the immense demand of local authorities, other government agencies, estate offices, and the private sector. It drew upon the research already carried out for these agencies and businesses by the Department of Physical Geography and the Laboratory of Applied Geoinformatics, as well as by the well-known and respected mathematics and informatics faculty of the University of Szeged. Launching the geology specialisation was aimed at satisfying permanent demand for our students by industries such as the state-owned oil company MOL Rt. that has major production and refining facilities near Szeged.

The latest changes to the curriculum took place only this year, so we will have to continue monitoring the effectiveness of the programme for several years to make sure we reach our goals. At the same time, we are already considering other improvements such as the introduction of special seminars on timely and highly specialised subjects. These would allow us offer coverage of some topics not included in the curriculum and to bring small groups of 5-10 students together with well-known scientists from outside the university.

\section{Market Research into the Employment of Geographers}

An important part of the curriculum was to make sure the professional geographers were gaining the skills necessary to make them competitive in the labour market and that employment opportunities existed or could be established for them. Indeed, one of the first steps we took in developing the programme was to assemble advisory panels including representatives from both the private sector and government agencies, as has been done for similar programmes in Germany and the United Kingdom (Schrettenbrunner, 1990; Marsden, 1990). Within the first few years of the programme, 225 students completed the professional geographer course at the University of Szeged, as did 
$350-400$ students at other universities, so it was possible, quite quickly, to begin evaluating the programme.

A team from the Marketing Management Department of Szeged University drew up a plan of evaluation on behalf of the three institutions that first offered the programme. The cooperation of three institutions of higher education in evaluating a shared programme was a unique feature of the plan because Hungarian institutions usually act alone in evaluating their programmes. The project had two goals. First, we had to estimate potential employment opportunities for our graduates. Second, we had to make sure that employers were aware of the new programme and of the skills possessed by its graduates. Our aim, in part, was to begin a campaign to market our graduates more effectively. But this is difficult to do, as the literature points out (Kotler, 1992), if employers lack information about a 'product' such as our graduates. The projects focused on:

(1) the geographical needs of employers in terms of their use of geospatial data and demand for the expertise offered by college-educated geographers;

(2) awareness among employers of geography and employability of geography students.

In effect, the project focused on issues of market research, product positioning and advertising the skills of geographers. The project was undertaken in three stages.

\section{Product Research and Analysis}

In the first stage of research we sought to inventory the skills and abilities of our students from the institutional standpoint of what they studied and the personal perspective of the students' own experiences in the programme. We gathered information from course syllabi and records and surveyed lecturers teaching in the programme. We also surveyed students in the programme and used focus groups to gather detailed information about their experiences. Using the results of the surveys and focus groups it was possible to compare and contrast positive and negative opinions expressed about the programme. These comments had the added side benefit of providing feedback on the programme as it is offered in the three universities. Once we had gathered this information, we used the DACUM (Developing A Curriculum) method to collate our findings. We arranged the skills revealed into an activity matrix with skills matched to job tasks (Table II). The matrix was regrouped and ordered into constellations of skills that our graduates offered to employers. Once we had identified job tasks, we moved to the second stage of the project: estimating demand for the skills of our professional geographers. In selecting members of the focus groups, half were chosen by random sampling, half using controlled samples drawn from groups of teachers and prominent students. The potential employee organisations were chosen by random sampling.

\section{Market Research into the Demand for Geographers}

This was the most important part of our study and the one on which we invested the most time and money. It served both to estimate the needs and expectations of the potential employers, the 'consumers' of our graduates, and to measure to what degree employers knew about our programmes in professional geography. Again, this information had the useful side benefit of providing feedback to the universities that could be used to improve and modernise the curriculum still further.

We applied primary survey research methods to gather data about market conditions. 


\begin{tabular}{|c|c|c|c|c|c|c|c|c|c|c|}
\hline $\begin{array}{l}\text { A } \\
\text { Geographical } \\
\text { research }\end{array}$ & $\begin{array}{l}\text { Al } \\
\text { Setting up } \\
\text { research } \\
\text { projects }\end{array}$ & $\begin{array}{l}\text { A2 } \\
\text { Planning } \\
\text { research } \\
\text { projects }\end{array}$ & $\begin{array}{l}\text { A3 } \\
\text { Carrying } \\
\text { out research } \\
\text { projects }\end{array}$ & $\begin{array}{l}\text { A4 } \\
\text { Publishing } \\
\text { results }\end{array}$ & $\begin{array}{l}\text { A5 } \\
\text { Self- } \\
\text { development }\end{array}$ & $\begin{array}{l}\text { A6 } \\
\text { Connecting } \\
\text { to other } \\
\text { research } \\
\text { issues }\end{array}$ & $\begin{array}{l}\text { A7 } \\
\text { Carrying out } \\
\text { environmental } \\
\text { measurements }\end{array}$ & $\begin{array}{l}\text { A8 } \\
\text { Using } \\
\text { research } \\
\text { equipment }\end{array}$ & A9 & $\mathrm{A} 10$ \\
\hline $\begin{array}{l}\text { B } \\
\text { Organisation } \\
\text { and system } \\
\text { management } \\
\text { (environmental } \\
\text { protection or } \\
\text { regional } \\
\text { development } \\
\text { organisations } \\
\text { etc.) }\end{array}$ & $\begin{array}{l}\text { BI } \\
\text { Cannot plan } \\
\text { spatial } \\
\text { geographical } \\
\text { organisations } \\
\text { or systems }\end{array}$ & $\begin{array}{l}\text { B2 } \\
\text { Controlling } \\
\text { and valuing } \\
\text { geographical } \\
\text { systems. }\end{array}$ & $\begin{array}{l}\text { B3 } \\
\text { Monitoring } \\
\text { spatial } \\
\text { systems }\end{array}$ & $\begin{array}{l}\text { B4 } \\
\text { Developing } \\
\text { a GIS }\end{array}$ & $\begin{array}{l}\text { B5 } \\
\text { Evaluating } \\
\text { spatia! } \\
\text { systems }\end{array}$ & $\begin{array}{l}\text { B6 } \\
\text { Applying } \\
\text { TQM } \\
\text { systems }\end{array}$ & $\begin{array}{l}\text { B7 } \\
\text { Understand } \\
\text { new } \\
\text { possibilities } \\
\text { of system } \\
\text { applications }\end{array}$ & $\begin{array}{l}\text { B8 } \\
\text { Cannot } \\
\text { overview } \\
\text { cost- } \\
\text { benefit } \\
\text { conditions } \\
\text { of systems } \\
\text { or } \\
\text { organisations }\end{array}$ & $\begin{array}{l}\text { B9 } \\
\text { Not abie to } \\
\text { plan systern } \\
\text { strategic } \\
\text { development }\end{array}$ & $\begin{array}{l}\text { B10 } \\
\text { Can apply } \\
\text { system or } \\
\text { organisation } \\
\text { legal } \\
\text { conditions }\end{array}$ \\
\hline $\begin{array}{l}\text { C } \\
\text { Leadership } \\
\text { and } \\
\text { management }\end{array}$ & $\begin{array}{l}\mathrm{Cl} \\
\text { Cannot } \\
\text { make } \\
\text { leadership } \\
\text { decisions }\end{array}$ & $\begin{array}{l}\text { C2 } \\
\text { Can prepare } \\
\text { conditions for } \\
\text { leadership } \\
\text { decisions }\end{array}$ & $\begin{array}{l}\text { C3 } \\
\text { Cannot } \\
\text { manage } \\
\text { human } \\
\text { resources }\end{array}$ & $\begin{array}{l}\mathrm{C} 4 \\
\text { Cannot } \\
\text { lead team }\end{array}$ & $\begin{array}{l}\text { C5 } \\
\text { Follows } \\
\text { leader's } \\
\text { orders }\end{array}$ & $\begin{array}{l}\text { C6 } \\
\text { Participates } \\
\text { in teamwork }\end{array}$ & $\begin{array}{l}\text { C7 } \\
\text { Uses human } \\
\text { resource data }\end{array}$ & $\begin{array}{l}\text { C8 } \\
\text { Knowing } \\
\text { and } \\
\text { applying } \\
\text { legal } \\
\text { conditions }\end{array}$ & C9 & $\mathrm{ClO}$ \\
\hline $\begin{array}{l}\text { D } \\
\text { Communication }\end{array}$ & $\begin{array}{l}\text { D1 } \\
\text { Having } \\
\text { communication } \\
\text { skills }\end{array}$ & $\begin{array}{l}\text { D2 } \\
\text { Using } \\
\text { communication } \\
\text { equipment }\end{array}$ & $\begin{array}{l}\text { D3 } \\
\text { Making } \\
\text { presentations }\end{array}$ & $\begin{array}{l}\text { D4 } \\
\text { Not } \\
\text { familiar } \\
\text { with } \\
\text { promotion }\end{array}$ & $\begin{array}{l}\text { D5 } \\
\text { Speaking } \\
\text { foreign } \\
\text { languages }\end{array}$ & D6 & D7 & D8 & D9 & D10 \\
\hline $\begin{array}{l}\text { E } \\
\text { Geographical } \\
\text { monitoring }\end{array}$ & $\begin{array}{l}\text { El } \\
\text { Planning } \\
\text { monitoring } \\
\text { systems }\end{array}$ & $\begin{array}{l}\text { E2 } \\
\text { Running } \\
\text { monitoring } \\
\text { systems }\end{array}$ & $\begin{array}{l}\text { E3 } \\
\text { Developing } \\
\text { monitoring } \\
\text { systems }\end{array}$ & $\begin{array}{l}\text { E4 } \\
\text { Valuing } \\
\text { monitoring } \\
\text { results }\end{array}$ & $\begin{array}{l}\text { E5 } \\
\text { Knowing } \\
\text { and } \\
\text { applying } \\
\text { legal } \\
\text { conditions }\end{array}$ & E6 & E7 & E8 & E9 & E10 \\
\hline $\begin{array}{l}\text { F } \\
\text { Information }\end{array}$ & $\begin{array}{l}\text { Fl } \\
\text { Planning } \\
\text { information } \\
\text { collection } \\
\text { systems }\end{array}$ & $\begin{array}{l}\text { F2 } \\
\text { Collecting } \\
\text { data in } \\
\text { designed } \\
\text { systems }\end{array}$ & $\begin{array}{l}\text { F3 } \\
\text { Using } \\
\text { computer } \\
\text { databases }\end{array}$ & $\begin{array}{l}\text { F4 } \\
\text { Valuing } \\
\text { information }\end{array}$ & $\begin{array}{l}\text { F5 } \\
\text { Using } \\
\text { valued } \\
\text { information }\end{array}$ & $\begin{array}{l}\text { F6 } \\
\text { Knowing } \\
\text { and } \\
\text { applying } \\
\text { legal } \\
\text { conditions }\end{array}$ & F7 & F8 & F9 & F10 \\
\hline $\begin{array}{l}\text { G } \\
\text { Administration }\end{array}$ & $\begin{array}{l}\text { GI } \\
\text { Using word } \\
\text { processor } \\
\text { and } \\
\text { publishing } \\
\text { software }\end{array}$ & $\begin{array}{l}\text { G2 } \\
\text { Making } \\
\text { reports and } \\
\text { applications }\end{array}$ & $\begin{array}{l}\text { G3 } \\
\text { Knowing } \\
\text { and } \\
\text { applying } \\
\text { legal } \\
\text { conditions }\end{array}$ & G4 & G5 & G6 & G7 & G8 & G9 & Gi0 \\
\hline
\end{tabular}


Do not use geographical information

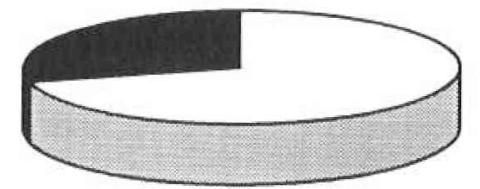

Use geographical information

Figure 3. Use of geographical information by the firms surveyed in this study.

Knows about the

course and

institutions where

taught $28 \%$
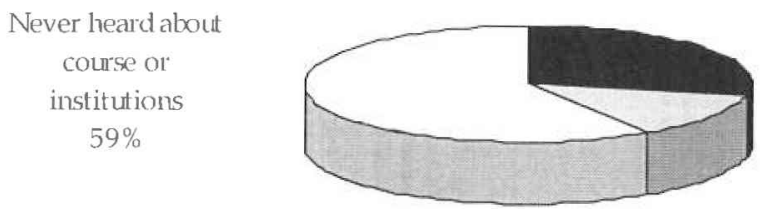

Knows aboul the course but not about institutions where taught $13 \%$

FIgURE 4. Awareness of geography programmes and courses among employers.

These included a random sample of companies surveyed by telephone using a questionnaire that queried firms about their use of geospatial data, the geographical skills employed by members of their workforces, and their awareness of geography both as a discipline and as a university subject (Churchill, 1988). Questionnaires were completed for 113 firms. The results indicate high potential demand for geographers, but little awareness of the geography programmes (Figs 3 and 4). This is much as we suspected when we began the study. One of the more interesting findings involved probing respondents for their awareness of other disciplines (our 'competitors') that provided employees with valuable workplace skills. The discipline that ranked higher than geography was engineering, both because of its traditional positive image and because of the knowledge engineering graduates had to offer businesses.

\section{The Campaign to Raise Awareness of Geography's Value}

With this finding in mind, we moved into the final stage of our project - an effort to influence the market and perceptions of geography. This target group included local and national government agencies and authorities, as well as two groups of private firms: those that handle government projects and those involved in environmental management and risk assessment. Our contact with the private firms was through their public relations units. The campaign used direct mail, advertising and site visits. The first step involved direct mailings to 1000 employers, including essentially all of the Hungarian firms in the target groups. According to the responses we received, we visited 50 employers in person both to provide them with more information about our programme and to gather information about their need for professional geographers (Fig. 5). As part of the campaign, we also placed advertisements in business newspapers and periodicals. 


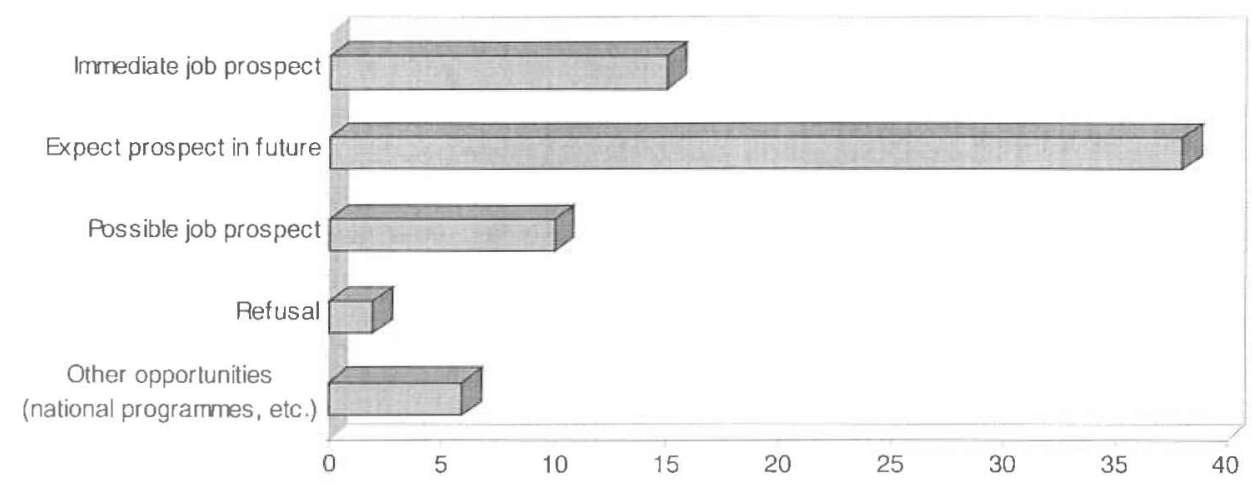

FIGURE 5. The results of the visits to employers in percentage.

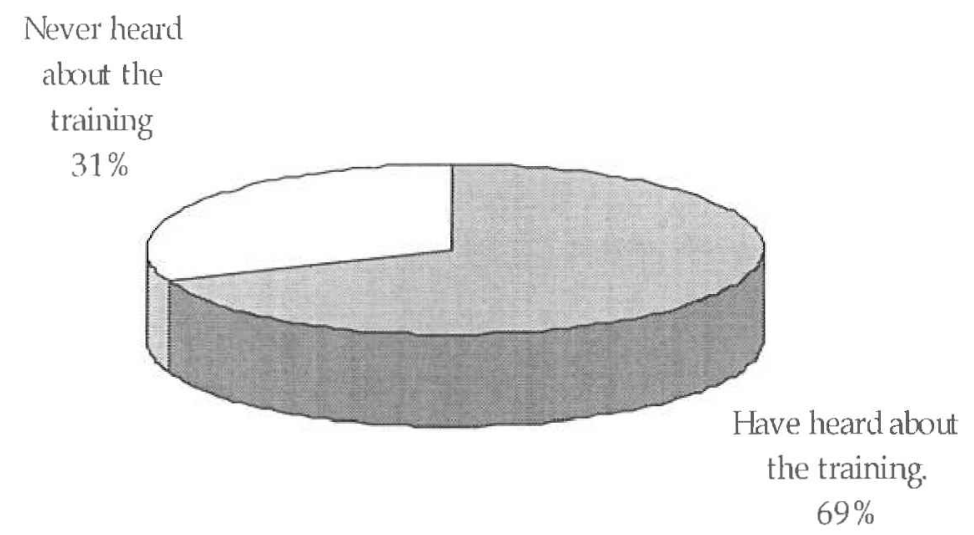

Figure 6. Awareness of geography and programmes after the campaign.

After we completed the advertising campaign, we again surveyed employers using the same methodology employed in the second stage of the project (Fig. 6). Our interest was in measuring the effectiveness of our campaign. The findings indicate that employers had a better grasp of the skills our graduates could offer their firms and greater awareness of our programmes. We judged the campaign a success, particularly in light of how new our programme is. Based on the results, we are planning another campaign that will seek to improve perceptions of geographers in comparison with other disciplines such as engineering.

\section{Conclusion}

So far we are pleased with the performance of our new programme to train professional geographers in Hungarian universities. It seems to be an effective response both to changing workforce needs and changing conditions of higher education in Hungary. Yet we do not intend to become complacent. Our research yielded valuable feedback about the performance of the new professional geography programme that we plan to use to 
improve them. Monitoring of the programme and of employment opportunities will need to be extended into the future as Hungary's economy and educational system continue to adjust to new challenges and opportunities. For the moment, however, we are satisfied with the programme both as a model for innovation in Hungarian higher education and as an example of what geographers might accomplish in neighbouring countries faced with some of the same economic and educational challenges.

We believe that the model can be adapted to the transformation of other programmes in Central and Eastern Europe and help as well to raise the image of geographers as offering spatial thinking and complex problem-solving skills to government and business.

Correspondence: Mezõsi Gábor, Chair, Department of Physical Geography, University of Szeged, H-6722, Szeged, POB 653 Hungary. Mucsi László, Department of Physical Geography, University of Szeged, H-6722, Szeged, POB 653 Hungary. Garamhegyi Ábel, Department of Marketing and Management, University of Szeged, H-6722, Szeged, POB 653 Hungary.

\section{REFERENCES}

Churchill, G.A., JR. (1988) Basic Marketing Research (Orlando, Dryden Press).

Enyed, GY. (1984) Rural Public Services. International comparison (Boulder, Westview Press).

Enyedi, GY. (1988) Phases of Urban Development (Budapest, Akadémiai Kiadó).

Haubrich, H. (1996) Geographical education 1996. Results of a survey in 38 countries, IGU CGE Newsletter, 32, pp. 1-28.

KOTLER, P. (1992) Marketing Management (Budapest, Mûszaki Könyvkiadó).

MARSDEN, W.E. (1990) The role of geography in education in England and Wales, GeoJournal, 20(1), pp. 25-31.

PÉCSI, M. \& RÉTVÁRI, L. (1984) Concept of geographical environment and environmental mapping, Geographical Mosaic, pp. 1-8.

ProbÁld, F. (1998) The position of geography teaching today, Földrajzi Közlöny, 122(1-2), pp. 29-42. SChrettenbrunner, H. L. (1990) Geography in general education in the Federal Republic of Germany, GeoJounal 20(1), pp. 33-36. 
